Portland State University

PDXScholar

Environmental Science and Management

Faculty Publications and Presentations

2-24-2015

\title{
Modeling Predator Habitat to Enhance Reintroduction Planning
}

\author{
Shiloh Michael Halsey \\ Portland State University, shilohhalsey@gmail.com \\ William J. Zielinski \\ USDA Forest Service \\ Robert M. Scheller \\ Portland State University, rmschell@pdx.edu
}

Follow this and additional works at: https://pdxscholar.library.pdx.edu/esm_fac

Part of the Environmental Health and Protection Commons, Environmental Monitoring Commons, Forest Management Commons, and the Sustainability Commons

Let us know how access to this document benefits you.

\section{Citation Details}

Halsey, S.M., Zielinski, W.J., Scheller, Robert M. (2015). Modeling predator habitat to enhance reintroduction planning. Landscape Ecology.

This Article is brought to you for free and open access. It has been accepted for inclusion in Environmental Science and Management Faculty Publications and Presentations by an authorized administrator of PDXScholar. Please contact us if we can make this document more accessible: pdxscholar@pdx.edu. 


\title{
Modeling predator habitat to enhance reintroduction planning
}

\author{
Shiloh M. Halsey • William J. Zielinski • \\ Robert M. Scheller
}

Received: 21 May 2014/ Accepted: 16 February 2015

(C) Springer Science+Business Media Dordrecht 2015

\begin{abstract}
Context The success of species reintroduction often depends on predation risk and spatial estimates of predator habitat. The fisher (Pekania pennanti) is a species of conservation concern and populations in the western United States have declined substantially in the last century. Reintroduction plans are underway, but the ability of the species to establish a selfsustaining population is affected by predation from its primary predator, the bobcat (Lynx rufus).

Objectives To develop a habitat model that incorporates both habitat of the focal species and the spatial patterning of predator habitat. To locate areas of densely aggregated habitat that would be suitable for reintroduction.

Methods Using camera survey data, we modeled the association between bobcat presence and environmental features using a classification tree. We applied this model to a spatial analysis of fisher habitat and identified reintroduction areas in the southern Washington Cascade Range.
\end{abstract}

S. M. Halsey $(\bowtie) \cdot$ R. M. Scheller

Dynamic Ecosystems and Landscapes Lab, Portland State University, 1719 SW 10th Ave, Portland, OR 97201, USA e-mail: shilohhalsey@gmail.com

\section{W. J. Zielinski}

Redwood Sciences Laboratory, USDA Forest Service Pacific Southwest Research Station, 1700 Bayview Drive, Arcata, CA 95521, USA
Results The classification tree predicted bobcat detection based on elevation and mean tree diameter. The final model identified fisher reintroduction locations primarily in or near existing wilderness areas. Fisher habitat areas identified considering both habitat and predation risk differed from those identified without considering predation.

Conclusion Our spatial approach is unique among fisher reintroduction plans by accounting for both resource requirements and risk of predation. It can be used as a template for future reintroduction efforts in other regions and for other species. Using similar models to refine population management and reintroduction should improve the probability of successful population establishment and stability.

Keywords Fisher (Pekania pennanti) - Bobcat (Lynx rufus) · Reintroduction · Predation · Habitat modeling $\cdot$ Classification tree

\section{Introduction}

A spatial assessment of predation risk is an essential step in modeling habitat for a prey species (Banks et al. 2002; Ormerod 2002; Moseby et al. 2011; McCleery et al. 2013). Relative risk varies with the abundance and distribution of predator habitat, a consideration that should affect the management of species of conservation concern (Mao et al. 2005; Atwood et al. 
2009; Poessel et al. 2011; Gorini et al. 2012; Wengert et al. 2014). A thorough habitat and risk management strategy should consider the habitat needs of the prey as well as the habitat of its primary predators. We evaluated the habitat of a carnivore of conservation concern (the fisher, Pekania pennanti) as affected by the spatial distribution of habitat for its primary predator, the bobcat (Lynx rufus).

The fisher is a medium-sized member of the Mustelidae whose historic range in the western United States once spread throughout the northern Rocky Mountains, the Cascade and Coast Ranges, and the Sierra Nevada (Powell 1993; Lofroth et al. 2010). Due to trapping and habitat fragmentation, the abundance of fisher in the Pacific states has declined dramatically and is now limited to several, isolated populations in southwestern Oregon, northern California, the southern Sierra Nevada in central California, and the Olympic Peninsula of Washington (Ingram 1973; Aubry and Lewis 2003; Spencer et al. 2011; Lewis et al. 2012). Trapping of fishers in Washington was prohibited in 1933, but populations were already substantially reduced; statewide surveys from 1989 to 2000 failed to detect the presence of fishers (Aubry and Houston 1992; Lewis and Hayes 2004). The fisher has recently been reintroduced to the Olympic Peninsula, but is still listed as an endangered species in Washington (Lewis et al. 2011). The U.S. Fish and Wildlife Service has proposed listing the West Coast distinct population segment of fisher as threatened under the Endangered Species Act (U.S. Federal Register, 7 October 2014).

Reintroductions are an effective way to reestablish carnivores that have been extirpated from their native habitat, and the fisher has been one of the most successfully reintroduced carnivores in North America (Vinkey et al. 2006; Schwartz 2007; Ewen et al. 2012; Lewis et al. 2012). Fisher populations, however, expand slowly and are particularly vulnerable to bobcat predation (Gilbert 2000; Lewis et al. 2011; Wengert et al. 2014). Bobcats are the most common predator on fishers in California, responsible for up to $77 \%$ of female fisher mortality (Wengert 2013). Moreover, most bobcat predation on females occurs from March to July, when females may have dependent young whose secondary deaths can magnify the negative effect of bobcat predation on the fisher population (Wengert et al. 2014). Fishers released into the Olympic Peninsula of Washington between 2008 and 2010 were fitted with radio collars, and although the causes of their deaths was not always determined, it appears that predation, especially by bobcat, was a significant mortality factor (Lewis et al. 2011). Predation was also a dominant factor in a fisher translocation effort in Montana where over half of the fishers were killed by predators (Roy 1991). Although coyotes (Canis latrans) and mountain lions (Puma concolor) prey on fishers, it occurs less commonly than predation by bobcats (Wengert 2013). Further, the large home ranges of mountain lions would result in distribution models that would be more general and less likely to affect choices for fisher reintroduction sites.

The distribution of bobcats in the Pacific Northwest is not well understood and, given their role as a key predator, bobcat habitat analysis should be a part of reintroduction planning for fishers. Released fishers will inevitably encounter bobcat predation as they expand from reintroduction sites into the broader landscape, but the likelihood of these encounters can be reduced by selecting reintroduction locations where bobcat abundance is likely to be low. Because female fishers are expected to maintain more fidelity to reintroduction sites than males (Lewis et al. 2011), mitigating the negative effects of bobcat predation at these sites may disproportionately benefit female fishers whose survival rates are the most influential demographic parameter influencing population growth (Buskirk et al. 2012).

Our goal was to locate areas where potential fisher habitat overlapped areas with a low likelihood of bobcat presence. We combined existing survey data with new camera survey results to develop a model of bobcat habitat in the southern Washington Cascades. We incorporated the results into a fisher habitat model and used these results to recommend areas of aggregated fisher habitat which would reduce predation and give transplanted fishers an improved chance to survive and reproduce. We intend to inform future fisher reintroductions in Washington and guide future monitoring and research. Our research used a novel approach to habitat modeling for reintroductions that can be used as a model for future release efforts in other regions and for other species. 


\section{Methods}

Study area

The Washington Department of Fish and Wildlife (WA-DFW) carried out a feasibility assessment in 2004 and identified the southern Washington Cascades, the Olympic Peninsula, and the North Cascades as possible locations for a reintroduction of fisher (Lewis and Hayes 2004). The Olympic Peninsula was chosen as the first location and reintroductions occurred in 2008, 2009 and 2010 (Lewis et al. 2011). Our study area in the southern Washington Cascades was highlighted as a candidate reintroduction region (Lewis 2013) and is centered on federal land, assuming that public lands are the most likely locations for reintroduction. The geographic center of the study area is located at 46.49102 latitude by 121.64149 longitude. The $9842 \mathrm{~km}^{2}$ study area encompasses the southern part of the Mt. BakerSnoqualmie (MBS) and Wenatchee National Forests (WNF) $\left(3351 \mathrm{~km}^{2}\right)$, Mount Rainier National Park (MRNP) (954 km²), and the Gifford Pinchot National Forest (GPNF) $\left(5537 \mathrm{~km}^{2}\right)$, which includes the Mount St. Helens National Volcanic Monument. The area is characterized by large tracts of coniferous forest and the volcanic peaks of Mount Rainier, Mount St. Helens, and Mount Adams. Douglas fir (Psuedotsuga menziesii), western hemlock (Tsuga heterophylla), red alder (Alnus rubra), bigleaf maple (Acer macrophyllum), western red cedar (Thuja plicata), and grand fir (Abies grandis) dominate the canopy of the Cascade Range. The forests of this region exist in varying stages of succession due to a history of logging and fires (Knick et al. 1985).

\section{Data layers for modeling}

We acquired the forest data layers from Landscape Ecology, Modeling, Mapping and Analysis (LEMMA: http://lemma.forestry.oregonstate.edu). The data were derived from a gradient nearest neighbor approach, which uses a multivariate gradient analysis linking field plot data, satellite imagery, and maps of environmental variables to create a raster grid of large ecoregions in California, Oregon, and Washington. Raster data were delivered and analyzed in a $30 \mathrm{~m}$ resolution. The accuracy of the LEMMA data was estimated by comparing predicted values with measurements from plots on the ground; the correlation coefficient and root mean squared error (normalized measure) for canopy cover was 0.75 and 0.20 and for QMDA was 0.72 and 0.43 , respectively (http:// lemma.forestry.oregonstate.edu/data/structure-maps). The inventory plots used to create the LEMMA data layers represent a span of 15 years of forest inventory data from western Washington, including the eastern portion of the Cascade Range. The spacing for groundvalidation sampling plots was roughly $5.5 \mathrm{~km}$, except for the plots in United States Forest Service Region 6 land, which are approximately $2.7 \mathrm{~km}$ apart, with a total of 5587 ground-truth plots (http://lemma. forestry.oregonstate.edu/data/structure-maps). The elevation layer was acquired from the United States Geological Survey (National Elevation Dataset: http:// ned.usgs.gov/).

Fisher habitat suitability map

A fisher habitat suitability map was created to identify areas of high suitability prior to considering the effect of bobcat distribution. The fisher habitat model was based on considering three variables often associated with fisher suitability which serve as critical components influencing survival: canopy cover, elevation, and tree diameter (quadratic mean diameter of all dominant and co-dominant trees: QMDA) (Powell 1993; Jacobson et al. 2003; Lewis and Hayes 2004; Zielinski et al. 2004; Davis et al. 2007; Lofroth et al. 2010; Aubry et al. 2013; Schwartz et al. 2013).

Fishers are strongly associated with dense canopy, which provides resting sites, refuge from predators, and habitat for prey (Carroll et al. 1999; Purcell et al. 2009; Zielinski et al. 2010; Scheller et al. 2011; Buchanan et al. 2013). Canopy also intercepts snow, and deep snow affects fisher survival by increasing their energy expenditure and reducing mobility (Aubry and Houston 1992; Krohn et al. 1995). On the basis of research conducted by Zielinski et al. (2004), we designated area with a canopy closure $>60 \%$ as suitable fisher habitat. Elevation is also a good predictor of fisher occurrence in western North America. High elevation areas are generally unsuitable for fishers due to increased snow depths, decreased prey density, lower tree cover, and smaller tree size as well as a lower density of snags and downed wood, which fishers use for resting and den sites (Powell 1993; Krohn et al. 1995; Jacobson et al. 
2003; Aubry et al. 2013). Aubry and Houston (1992) described historical records of fishers in western Washington up to $1800 \mathrm{~m}$, and Zielinski et al. (1997) found the highest elevation of northern California fishers to be around $1700 \mathrm{~m}$. Based on fisher habitat studies from the western United States and from similar recommendations of the feasibility assessment for the reintroduction of fishers in Washington, we set the upper limit of suitable habitat at 1676 m (Lewis and Hayes 2004; Zielinski et al. 2010; Spencer et al. 2011; Lewis 2014). Large diameter trees are important resources for resting and denning, however, intermediate-sized trees also provide value as resting sites and cover (Powell 1993; Lofroth et al. 2010; Schwartz et al. 2013). Lewis (2014) found that habitat use of female fishers reintroduced on the Olympic Peninsula was strongly related to the proportion of area in stands classified as having intermediate and large diameter trees. Zielinski et al. (2004) also found that the highest proportion area of fisher home ranges $(60.7 \%)$ in the Sierra Nevada were in areas with moderately sized trees $(29-61 \mathrm{~cm})$. In order to include both intermediate and large trees, we assigned areas with $>29 \mathrm{~cm}$ dbh QMDA as potential habitat. There are other factors that previous habitat models have highlighted as associated with fisher occurrence, such as total forest biomass, tree diameter diversity, percent hardwood, diameter of hardwoods, annual precipitation, and topographic relief (Carroll et al. 1999; Davis et al. 2007; Zielinski et al. 2010; Spencer et al. 2011). We have distilled a broad set of fisher habitat information to create a general yet predictive model that is specifically aimed at determining locations where the minimum requirements for fisher survival are present. This includes those areas where trees are large enough for denning and resting, and forested areas with enough canopy at low enough elevation to ensure there is adequate prey and snow depths that will not impede fisher movements.

Using this information, a simple algorithm was used to identify areas of suitable fisher habitat. We combined raster layers to determine locations where all three habitat components (cover, elevation, and QMDA) were of sufficient value. If canopy cover was $>60 \%$, QMDA was $>29 \mathrm{~cm}$, and elevation was $<1676 \mathrm{~m}$, a cell was considered suitable; if any one of these conditions was not met, it was unsuitable. To locate areas where habitat cells were most densely aggregated, we calculated cell density using the kernel density tool in ArcGIS. A search radius of $3534 \mathrm{~m}$ was used so that the density weighting function would only count cells within the diameter of an average female fisher home range of $9.8 \mathrm{~km}^{2}$ (Zielinski et al. 2004). This function gave greater weight to cells closest to the focal cell, the observation point, and this weight diminished until it reached the full search distance.

\section{Bobcat survey data}

Bobcat distributions were assembled using survey data obtained from three sources, each employing a similar survey method of baited, motion triggered camera sets on a 28-day survey duration (Zielinski and Kucera 1995; Long et al. 2010). The first set of surveys was conducted by the National Park Service at MRNP from 2002 to $2004(\mathrm{~N}=50)$. These surveys supplied data on a variety of species, including bobcats. The second set of surveys was collected from high elevation areas throughout the study area with surveys spanning from 2009 to $2013(\mathrm{~N}=169)$. This effort was carried out by the Cascades Carnivore Project, a non-profit organization focused on researching carnivores in the Cascade Range. We conducted surveys within the GPNF from June to November 2012. Our camera surveys were intended to determine detection and non-detection of bobcat $(\mathrm{N}=24)$. The surveys were conducted in a range of habitat types from high elevation alpine areas to low elevation coniferous forests. The three data sources supplied a total of 243 survey locations. Very little bobcat detection work has been conducted in the region so we had no estimates of probability of detection if present, thus failing to detect is not the same as absence. However, we applied a survey approach that reduces false absence in other species, and we assumed detection probabilities were similar to that of other mesocarnivores (Zielinski and Kucera 1995; Slauson et al. 2012).

\section{Modeling bobcat habitat}

Similar to fishers, habitat variations exist where bobcats are found, but certain habitat variables appear to be associated with bobcat occurrence. Tree cover is a common habitat feature for the species, and during the breeding season, fine scale habitat factors such as downed wood, understory density, caves, and rock outcroppings become increasingly important (Hansen 
2007; Tucker et al. 2008). We chose predictor variables that, collectively, represent structural and compositional characteristics that are often associated with descriptions of bobcat habitat. They included percent canopy cover, percent coniferous canopy cover, quadratic mean diameter of trees (QMDA), basal area of coniferous trees $>2.5 \mathrm{~cm} \mathrm{dbh}$, and elevation (Knick et al. 1985; Koehler and Hornocker 1989; Koehler et al. 1991; Neale and Sacks 2001; Benson et al. 2004; Blankenship et al. 2006; Litvaitis et al. 2006).

We created 100 m radius buffers ( $\sim 35$ raster cells) around each of our survey sites to assess neighboring forest conditions for the purpose of developing our bobcat model. Within each buffer, we calculated the mean of the forest structural and compositional data using the zonal statistics tool in ArcGIS.

We modeled bobcat occurrence as a function of the selected environmental predictor variables using a classification tree. Classification trees do not assume normal distributions and can include non-linear relationships (De'ath and Fabricius 2000; Muñoz and Felicísimo 2004; Baker et al. 2006). A classification tree highlights variation of a response variable by splitting the data, stepwise, at decision "nodes" and dividing the data into more homogeneous groups. The splitting of the variables is hierarchical; the variable at the top of the tree is the most important and each subsequent variable is only invoked after making a binary decision at the previous node. The classification tree was run using the 'rpart' package in R statistical software. The final classification tree was subjected to cross validation to evaluate how robust the predictions were to variations in the input data. We created twenty different subsets of the data (ten using $80 \%$ of the data to run the model and $20 \%$ to test the model, and ten using $85 \%$ of the data to run the model and $15 \%$ to test the model). We used two variations to examine if varying the subset amount affected validation.

Integrating bobcat and fisher modeling results

A spatial application of the bobcat model was necessary to identify areas with high and low likelihoods of bobcat detection that could be related to the areas of suitable fisher habitat. This required using the bobcat habitat classification tree to first rank spatial cells according to the likelihood of bobcat absence. The habitat values and rates of bobcat detection, as established in the classification tree, determined the location of the division (or 'break') points in the reclassification of raster cells in ArcGIS. Next, we summed the layers to determine ranks according to fisher habitat suitability and likelihood of bobcat absence in the raster cells. The kernel density tool was applied using a search radius of $3534 \mathrm{~m}$ and weighting more heavily those cells with a higher likelihood of bobcat absence. This highlighted areas of densely aggregated fisher habitat cells that also contained a relatively high likelihood of bobcat absence. Finally, we created maps showing the density of fisher habitat cells. Relative habitat values were distinguished using the natural breaks method in ArcGIS, which enabled us to locate the are as with the greatest densities of highly ranked fisher habitat and to highlight potential reintroduction locations.

\section{Results}

Fisher habitat analysis

The initial fisher habitat analysis, conducted prior to integrating it with the bobcat habitat model, revealed that the largest aggregations of predicted habitat occurred in three regions: (A) an area southeast of Mount Rainier along the northeast border of the Tatoosh Wilderness where the GPNF, WNF, and MRNP meet; (B) the southern tip of the GPNF near private lands; and $(\mathrm{C})$ the center of the GPNF southeast of Mount St. Helens (Fig. 1). The locations in the southern part of the study area are low elevation coniferous forests close to areas of light development. The northern location is a densely forested, mid to high-elevation area surrounded by three wilderness areas. Overall, the map depicts fairly evenly dispersed suitable habitat throughout most of the study area except in the eastern boundary near the drier parts of the Cascade Range.

\section{Bobcat survey data}

The bobcat surveys yielded 213 non-detection and 30 detection observations from 243 sites. Of the nondetection sites, 66 had either overlapping buffers with another non-detection site or were in very close proximity $(<2 \mathrm{~km})$ to a detection site. When a nondetection site overlapped another non-detection site or 
Fig. 1 Map of suitable fisher habitat density before the integration of the bobcat distribution model results. a The largest aggregation of suitable fisher habitat is located along the northeast border of the Tatoosh Wilderness just southeast of Mount Rainier. b The second largest aggregation of fisher habitat is located in the very southern part of the Gifford Pinchot National Forest near private lands. c The third ranking is made up of three smaller aggregations of dense habitat and is located in the center of the Gifford Pinchot National Forest southeast of Mount St. Helens

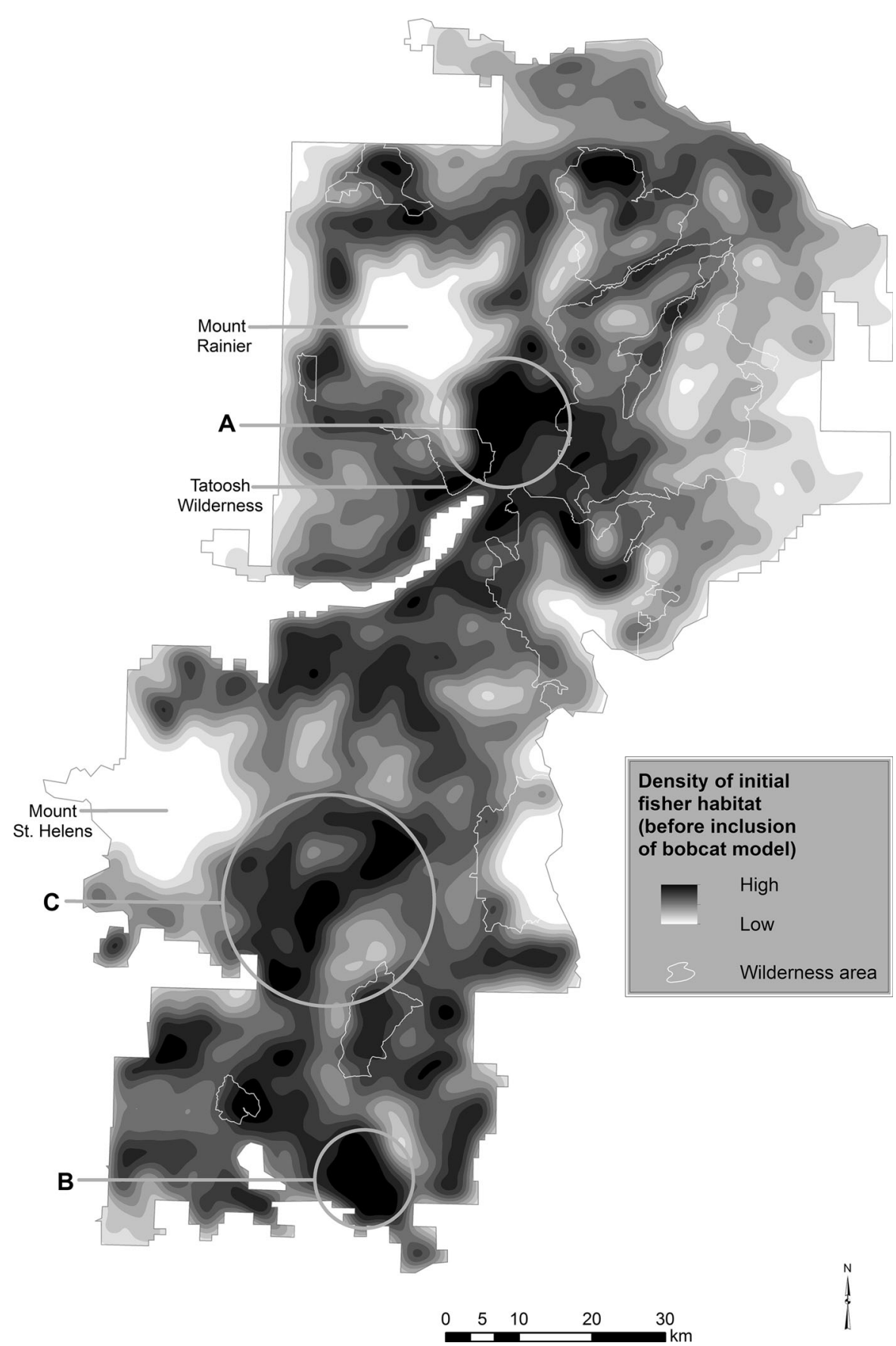

was within $2 \mathrm{~km}$ of the buffer of a detection site, the non-detection site was excluded to avoid overweighting a particular area as non-detection and to account for the possibility of a false negative. Excluding these 66 sites resulted in a total of 147 non-detection sites (Fig. 2).

\section{Classification tree}

The classification tree model had three nodes, using two variables: elevation and QMDA (Fig. 3). The tree's first split, and therefore its most important, was at $1303 \mathrm{~m}$ elevation. The probability of bobcat 


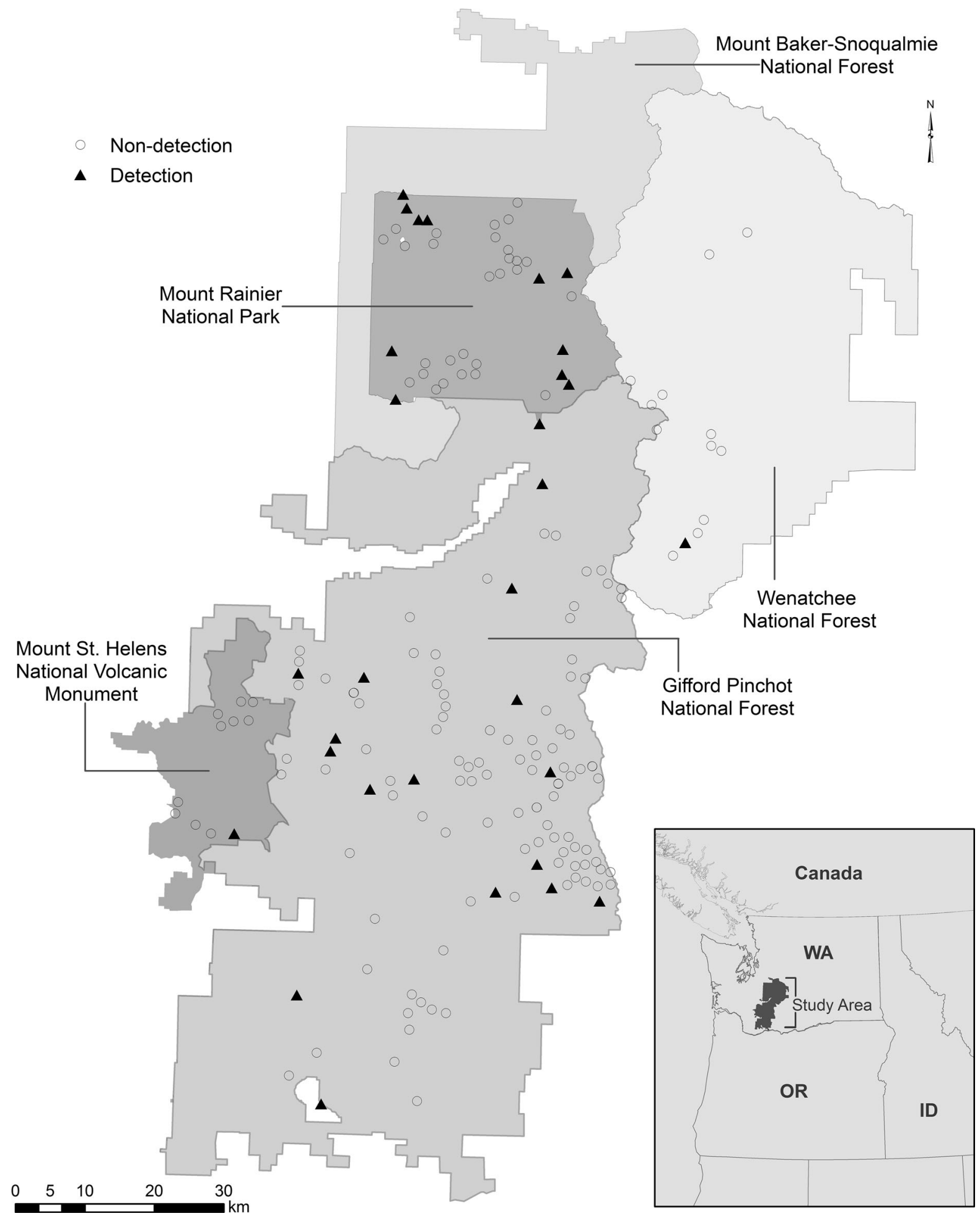

Fig. 2 Bobcat detection and non-detection sites in the study area of the Gifford Pinchot National Forest (including Mount St. Helens National Volcanic Monument), Mount Rainier National
Park, and the southern part of Mount Baker-Snoqualmie and Wenatchee National Forests. Inset map state abbreviations are as follows: WA Washington, $O R$ Oregon, and ID Idaho 
Fig. 3 Classification tree created through modeling the association of bobcat detection and non-detection with the predictor variables. Variables used in the creation of the tree are elevation (DEM) and quadratic mean diameter of trees (QMDA), as seen in the nodes of the tree. Elevation was measured in meters and QMDA was measured in centimeters. The 0 at the end of the first three branches represents a categorization of non-detection within the variable values at the nodes of the tree. The 1 on the last branch represents detection. The number on the left of the backslash represents the number of non-detection observations in this classification, while the number on the right represents the number of bobcat detection observations

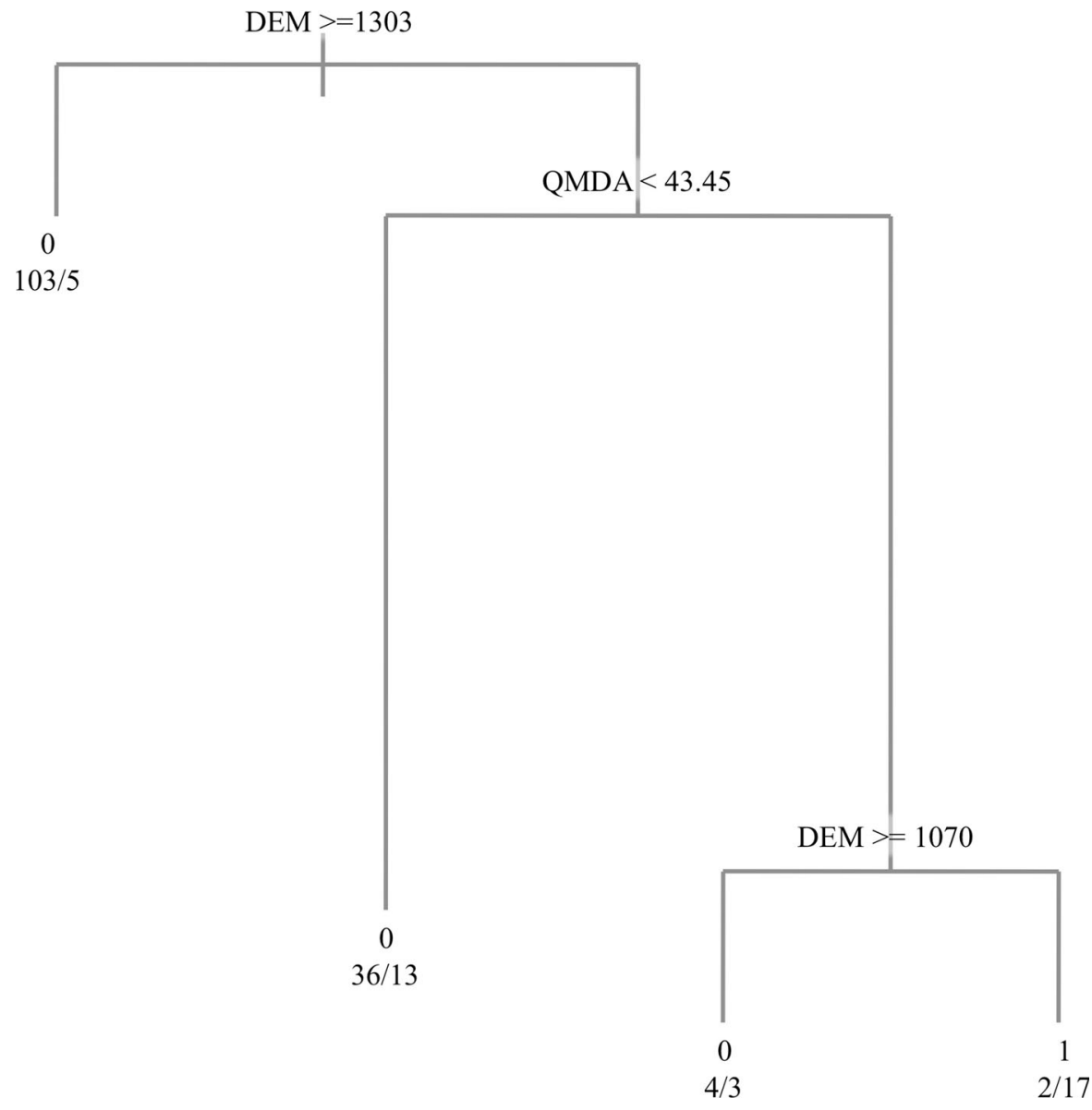

occurrence was low above this threshold, with 103 non-detections and only five detections above this elevation, a $95 \%$ rate of non-detection. The second node separated further the observations $<1303 \mathrm{~m}$ elevation into those that occurred in stands that were either above or below $43.45 \mathrm{~cm}$ QMDA. Below this tree diameter we found another high likelihood of absence, $73 \%$ non-detection, while cells above this threshold were further divided again. The last node occurred at an elevation value of $1070 \mathrm{~m}$, with a $57 \%$ likelihood of non-detection above this point. The highest correlation of presence (11\% non-detection) occurred below this value. In sum, bobcat habitat was characterized as low elevation forests with large diameter trees. Bobcats are less likely to occur in areas where average tree diameters are less than $43.45 \mathrm{~cm} \mathrm{dbh}$ and even less so in areas above $1303 \mathrm{~m}$ elevation. Cross validation of the classification tree revealed an average correct classification of $88 \%$, ranging from 85 to $91 \%$ for all iterations, indicating that the final tree model was robust to variation in input values (Table 1).

Spatial partitioning of bobcat and fisher habitat

We reclassified the cells in the raster layers according to both predicted bobcat absence and fisher habitat components. This process employed a numerically varied system of cell ranking to prevent data loss when using a raster calculator to sum the overlapping spatial cells $(0,1,2$, and 3 for elevation; 0,10 , and 20 for QMDA; then 0, 1, 2, and 3 according to bobcat detection; 0 and 10 for canopy cover). Other than the rank of 0 , which identifies unsuitable habitat, the values at this point do not reflect degrees of habitat suitability, instead they represent values of the variables conditioned on both habitat and bobcat detection. To start, the elevation layer and the QMDA layer 
Table 1 Ten iterations of the cross-validation of survey data using 80 or $85 \%$ of the data to run the model and 20 or $15 \%$ to validate

\begin{tabular}{|c|c|c|c|}
\hline $\begin{array}{l}\text { Subset } \\
\text { amount (\%) }\end{array}$ & $\begin{array}{l}\text { Correctly } \\
\text { classified (\%) }\end{array}$ & $\begin{array}{l}\text { Incorrectly } \\
\text { classified (\%) }\end{array}$ & Variables used \\
\hline \multirow[t]{10}{*}{$80 / 20$} & 91 & 9 & Elevation, tree diameter \\
\hline & 87 & 13 & Elevation, tree diameter \\
\hline & 90 & 10 & Elevation, tree diameter, canopy cover \\
\hline & 89 & 11 & Elevation, tree diameter \\
\hline & 87 & 13 & Elevation, tree diameter \\
\hline & 88 & 12 & Elevation, tree diameter \\
\hline & 87 & 13 & Elevation, tree diameter \\
\hline & 88 & 12 & Elevation, tree diameter \\
\hline & 86 & 14 & Elevation, tree diameter \\
\hline & 85 & 15 & Elevation \\
\hline \multirow[t]{10}{*}{$85 / 15$} & 88 & 12 & Elevation, tree diameter \\
\hline & 90 & 10 & Elevation, tree diameter, basal area of conifers \\
\hline & 89 & 11 & Elevation, tree diameter \\
\hline & 88 & 12 & Elevation, tree diameter \\
\hline & 87 & 13 & Elevation, tree diameter \\
\hline & 88 & 12 & Elevation, tree diameter, canopy cover \\
\hline & 89 & 11 & Elevation, tree diameter, canopy cover \\
\hline & 86 & 14 & Elevation, tree diameter \\
\hline & 89 & 11 & Elevation, tree diameter \\
\hline & 87 & 13 & Elevation, tree diameter, canopy cover \\
\hline
\end{tabular}

were summed (Fig. 4, upper left boxes) and the resulting values ( 0 through 23 ) were then reclassified down to $0,1,2$, and 3 according to bobcat nondetection rates as well as the two fisher habitat variables (Fig. 4, upper right and middle left boxes). This layer was combined with canopy cover and reclassified again into four categories resulting in a composite score reflecting bobcat detection and the suite of fisher habitat variables (Fig. 4, middle row and lower left box). The addition of the canopy cover layer used a similar nomenclature, combining the classified cells of canopy cover (0: unsuitable and 10: suitable) with the previously reclassified layers $(0,1,2$, and 3$)$. We reclassified the resulting values $(0,1,2,3,10,11$, 12 , and 13) a final time to reflect the likelihood of bobcat absence (3: $95 \%$ observed non-detection of bobcat, 2: $73 \%$ non-detection, 1: $57 \%$ non-detection, and $0: 11 \%$ non-detection or a cell without suitable fisher habitat components).

The reclassification procedure resulted in a cellbased map of predicted habitat suitability for fisher (Fig. 5). We then applied the kernel density function and gave higher weight to cells with a higher likelihood of bobcat absence. Cells ranked 0 were excluded from this function because these cells were classified as unsuitable or with a high bobcat detection rate. After applying the kernel density weighting function, three areas emerged as likely locations for fisher reintroduction (Fig. 6). The most densely aggregated habitat areas were: (A) the southern portion of the William O. Douglas Wilderness at the border of the GPNF and WNF, (B) the Norse Peak Wilderness northeast of Mount Rainier at the border of MBS and WNF, and (C) Indian Heaven Wilderness in the southern part of the GPNF.

\section{Discussion}

Our research uncovered previously unexplored variations of fisher habitat suitability by incorporating the influence of habitat of a key predator, the bobcat. We demonstrated that incorporating the results of the bobcat distribution model with the basic fisher habitat 
Fig. 4 Schematic diagram showing: (1) the reclassification and summing of spatial cells of the variables as designated by the bobcat model and fisher habitat values, (2) integration of the canopy cover layer, (3) summing and reclassification for the final rankings of the fisher habitat map, and (4) the creation of the density map

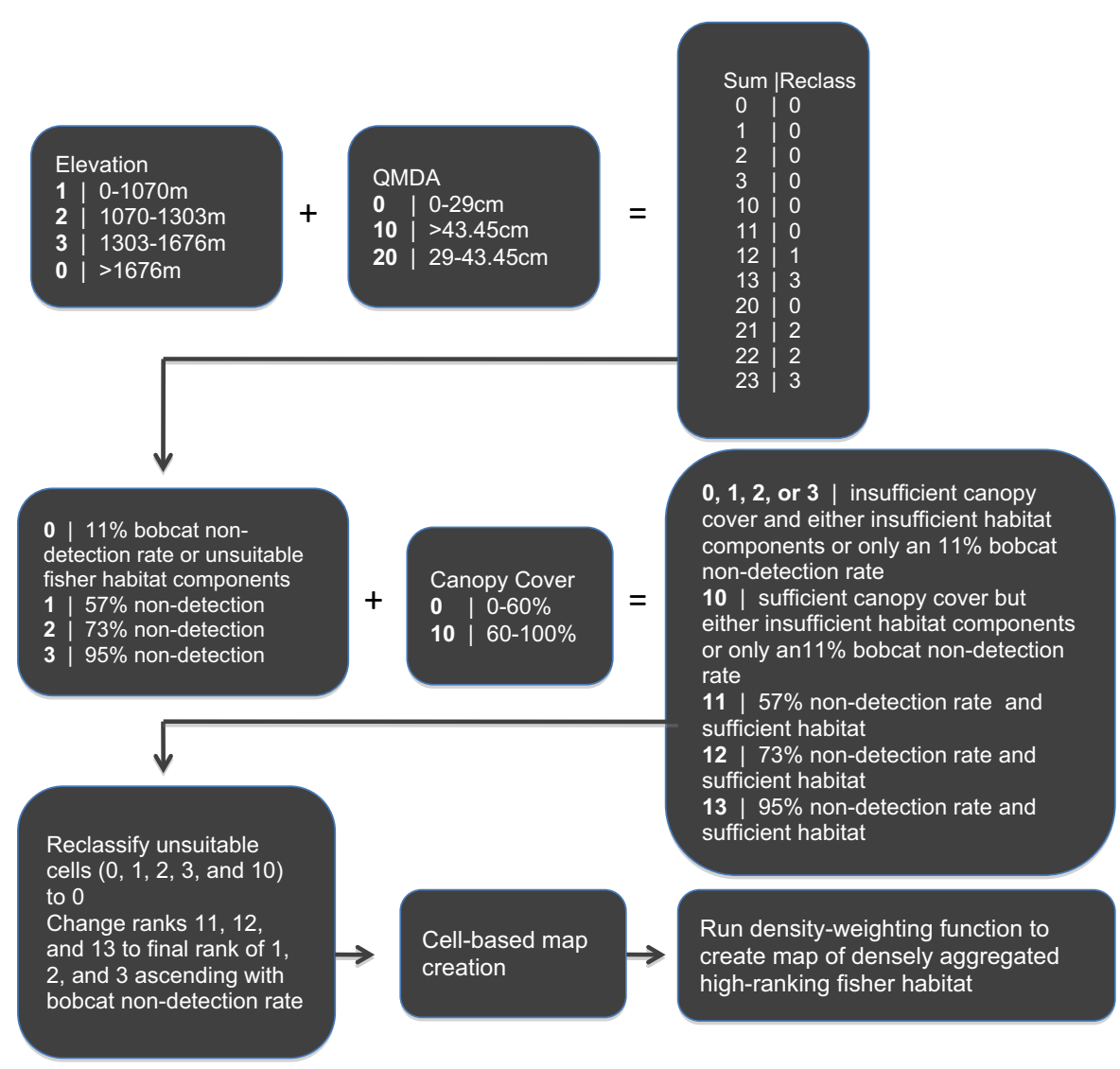

analysis substantially changed the spatial estimates of suitable fisher habitat (and potential reintroduction sites). Although efforts to minimize or mitigate effects of predation on reintroductions have been carried out for other species (Heezik et al. 1999; Seddon et al. 2007; Poessel et al. 2011), it has not been conducted for fishers. Predation can have significant effects on mammal populations, including carnivores (Creel and Creel 1996; Coonan et al. 2005; Moehrenschlager et al. 2007; Hunter and Caro 2008). Minimizing the threat of predation is especially important for species that are reintroduced after a long absence, for species that occur at low numbers, or for particularly sensitive species such as the fisher. Our work suggests that when considering habitat for a reintroduction, predation potential can be as influential as topographic and forest structural variables. There is increasing evidence concerning the importance of non-habitat factors in predicting potential habitat and habitat use, and that habitat alone can sometimes be a poor predictor of occupancy when the target species has a strong competitor or predator (Banks et al. 2002; Moseby et al. 2011; Poessel et al. 2011; Yackulic et al. 2014)

Comparing the two habitat maps in our analysis reveals important differences that can affect reintroduction planning for fishers. The final map (Fig. 6), which includes bobcat habitat data, is substantially different than the initial fisher habitat map (Fig. 1). The greatest difference was in the southern portion of the study area. The initial map highlights two main potential release areas and other densely aggregated regions in the low elevation forests of the southern GPNF, areas fairly close to larger roads and civilization. The final map, however, indicates that these areas have a low density of fisher suitability, with the only highly suitable area being in the mid-to-high elevation forests of Indian Heaven Wilderness. There is a general abundance of fisher habitat in the north and northeastern part of the final map. Potential habitat in most of this northern area was less pronounced in the initial map. In the final map, the three areas with the highest densities of fisher habitat are all located in 
Fig. 5 Cell-based representation showing potential fisher habitat and the varying levels of bobcat non-detection probability designated by the model

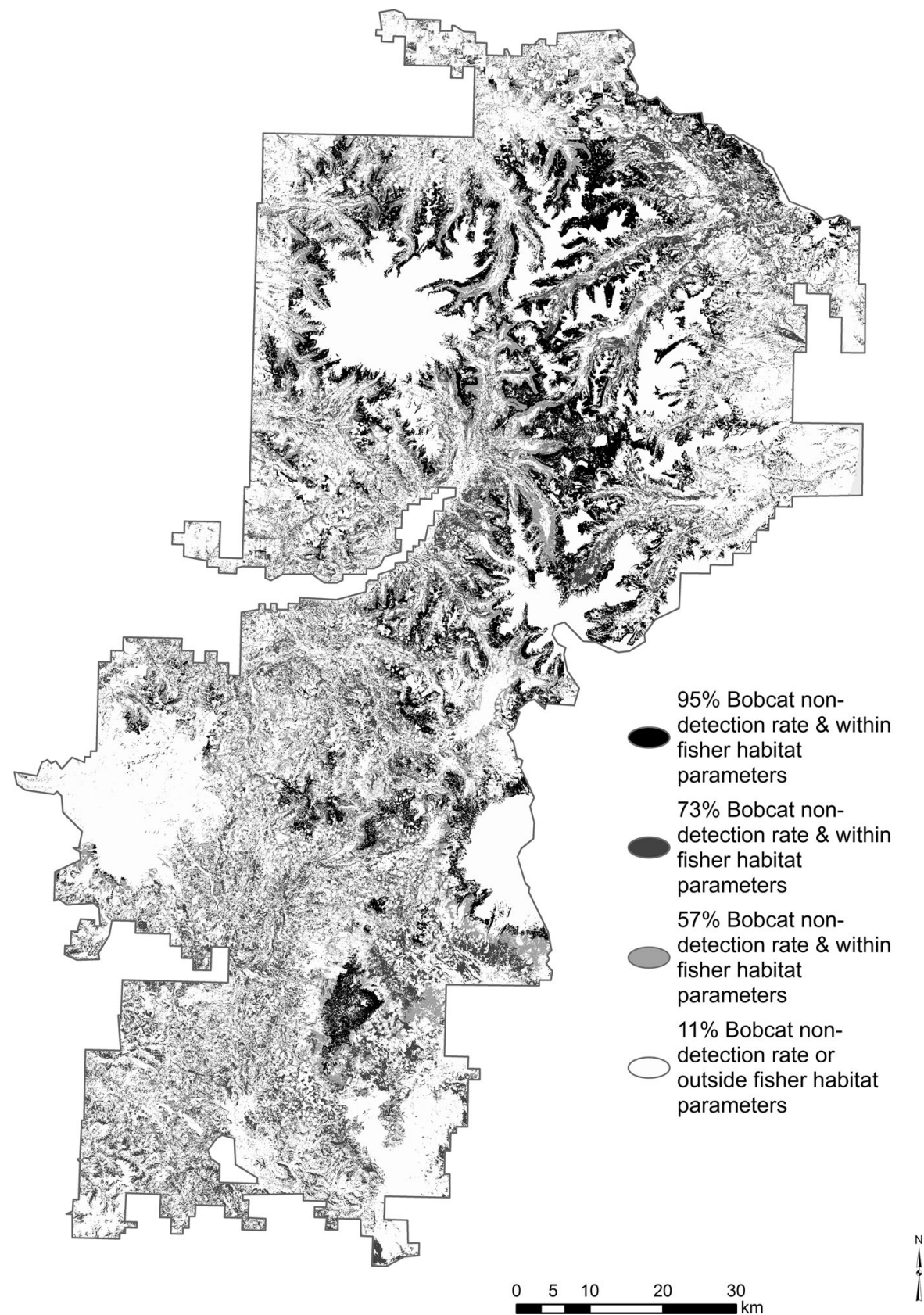

designated wilderness areas. There are also areas of similarity between the two maps, the largest of which is focused around the Norse Peak Wilderness. This area would be suitable for reintroduction with or without considering the influence of bobcats. Our analysis suggested that fisher reintroductions should occur at elevations above where bobcats are predicted to be most common, but at the upper range of predicted fisher habitat. Although this may be considered a liability, fishers do occur at these higher elevation forests (Aubry and Houston 1992; Krohn et al. 1995; Zielinski et al. 2010; Lewis 2014) and we believe that the negative effects of predation on new and small fisher populations is significant enough to compensate for the increased risk that may be incurred by reintroducing fishers at higher elevations. 
Fig. 6 Map of fisher habitat density conditioned on the features that contributed to the non-detection of bobcat. Cells ranked 3 (95\% rate of non-detection) are weighted most heavily, cells ranked 2 (73\% rate of non-detection) carry the middle weight, and cells ranked 1 (57\% rate of non-detection) are given the least weight. All cells measured in these ranks have sufficient fisher habitat parameters of canopy cover, elevation, and tree diameter. a The first highlighted reintroduction site and the area with the most densely aggregated fisher habitat cells is located in the William O. Douglas Wilderness where the Gifford Pinchot and Wenatchee National Forests meet. b Reintroduction site centered in the Norse Peak Wilderness northeast of Mount Rainier at the border of the Wenatchee and Mount Baker-Snoqualmie National Forests. c Reintroduction site centered in Indian Heaven Wilderness in the southern part of the Gifford Pinchot National Forest

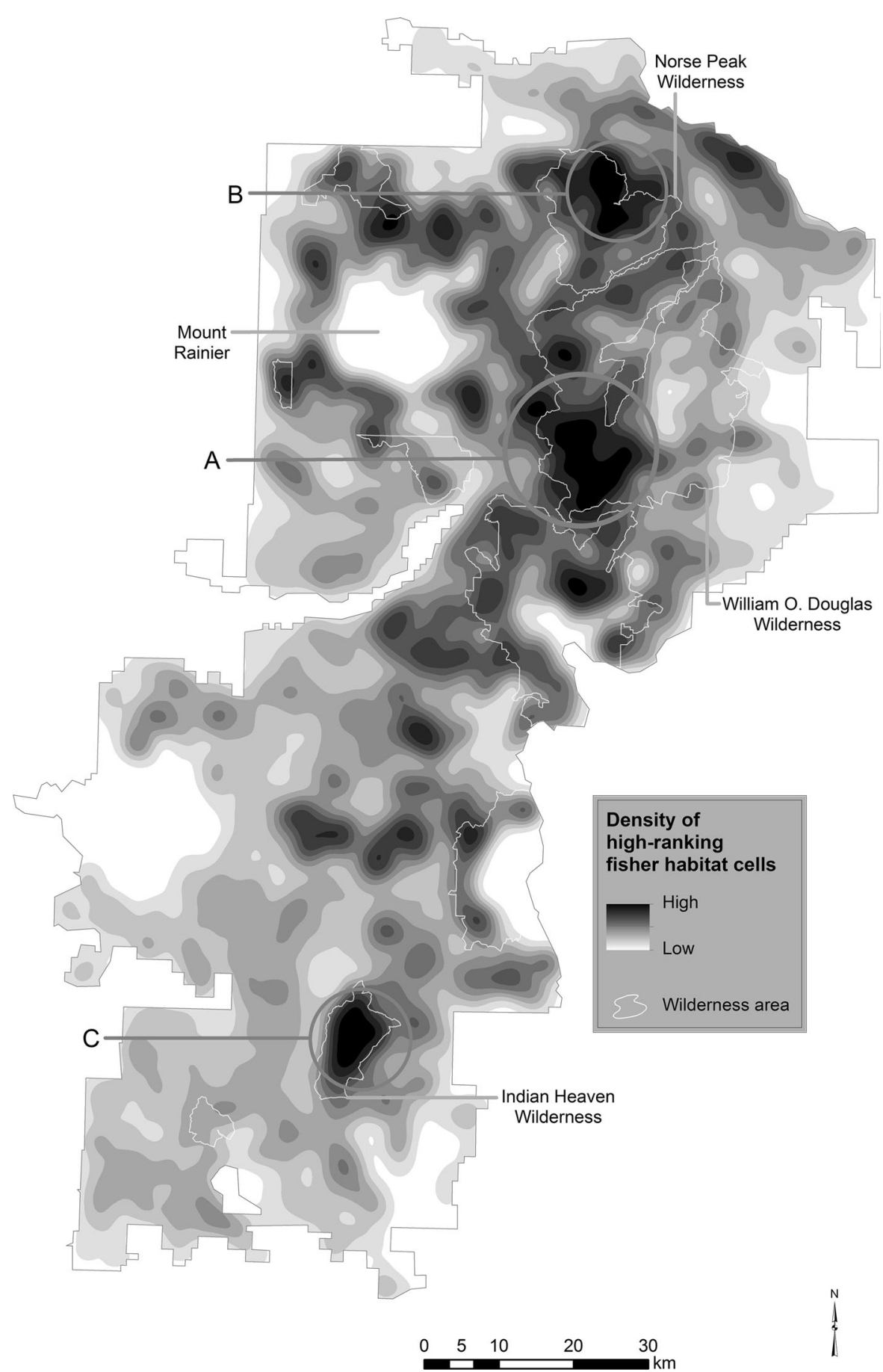

Fishers occasionally move large distances following release (Lewis et al. 2011) and it is likely that some individuals may settle in areas quite distant from release sites that are predicted to have the lowest threat from bobcats. We do not believe that the potentially long dispersal distances of some fishers negates the benefit of a priori planning to reduce the general impact of bobcats on fishers. Further, longer dispersal distances are more often associated with male fishers and less so with females (Lewis et al. 2011). Females 
are more often the victims of bobcat predation (Wengert et al. 2014), therefore females are the most likely to benefit from being translocated to sites where bobcat predation risk is lower.

Our cross validation suggests that our bobcat model is robust to variation in the input data. Post reintroduction monitoring in the study area would be needed to conduct traditional validation for the combined model and for validation of the fisher model. In the meantime, we feel that local validation of the fisher model would be unsuitable because the closest populations of fishers are in areas with substantially different forest types, such as the coastal forests of the Olympic Peninsula of Washington and the drier climate in southern Oregon. Zielinski et al. (2010) found fisher habitat in western coastal forests of California to be predicted by distinct spatial phenomenon associated with east to west precipitation gradients and other geographic predictors that would make inter-regional validation approaches less robust. To improve confidence in our model, we have instead extrapolated from a large body of research and a range of western United States fisher habitat areas to produce a general model for fisher habitat in our study area.

The results of our work can enhance the management and reintroduction of rare or endangered prey species. First, it can be applied to inform the location of future reintroductions when estimates of the spatial partitioning of habitat and predation risk can reduce mortality and increase population viability. Second, it can be used for hypothesis testing and as a predictive tool to highlight where individuals are expected to establish home ranges and to survive. If predators have negative effects on reintroductions, they are likely to also influence the establishment of home ranges and survival well after the early stages of reintroduction. Using release efforts as an investigative tool is an often-overlooked, yet important research opportunity (Seddon et al. 2007). Lastly, our approach can be used to identify specific locations for future research and monitoring efforts to examine the ongoing interactions of two species, particularly where their predicted habitat overlaps. This will increase the ability for researchers to examine whether species are experiencing competition, reduced dispersal, or a source-sink dynamic. This approach can refine monitoring and can direct analysis once reintroductions are underway and after home ranges have been established.
Acknowledgments The Gifford Pinchot Task Force (gptaskforce.org) generously supplied survey equipment and funding for this research. Survey data from the National Park Service and the Cascades Carnivore Project were valuable additions to the work. Greta Wengert offered important insights from fisher and bobcat studies in California, and Jeffrey Lewis (WA-DFW) provided valuable review comments.

\section{References}

Atwood TC, Gese EM, Kunkel KE (2009) Spatial partitioning of predation risk in a multiple predator-multiple prey system. J Wildl Manag 73:876-884

Aubry KB, Houston DB (1992) Distribution and status of the fisher (Martes pennanti) in Washington. Northwest Nat 73:69-79

Aubry KB, Lewis JC (2003) Extirpation and reintroduction of fishers (Martes pennanti) in Oregon: implications for their conservation in the Pacific states. Biol Conserv 114:79-90

Aubry KB, Raley CM, Buskirk SW, Zielinski WJ, Schwartz MK, Golightly RT, Purcell KL, Weir RD, Yaeger JS (2013) Meta-analyses of habitat selection by fishers at resting sites in the pacific coastal region. J Wildl Manag 77:965-974

Baker C, Lawrence R, Montagne C, Patten D (2006) Mapping wetlands and riparian areas using landsat ETM+ imagery and decision-tree-based models. Wetlands 26:465-474

Banks PB, Norrdahl K, Korpimäki E (2002) Mobility decisions and the predation risks of reintroduction. Biol Conserv 103:133-138

Benson JF, Chamberlain MJ, Leopold BD (2004) Land tenure and occupation of vacant home ranges by bobcats (Lynx rufus). J Mammal 85:983-988

Blankenship TL, Haines AM, Tewes ME, Silvy NJ (2006) Comparing survival and cause-specific mortality between resident and transient bobcats (Lynx rufus). Wildl Biol 12:297-303

Buchanan JB, Lundquist RW, Aubry KB (2013) Winter populations of Douglas' squirrels in different-aged Douglas-fir forests. J Wildl Manag 54:577-581

Buskirk SW, Bowman J, Gilbert JH (2012) Population biology and matrix demographic modeling of American martens and fishers. In: Aubry KB, Zielinski WJ, Raphael MG, Proulx G, Buskirk SW (eds) Biology and conservation of martens, sables, and fishers: a new synthesis. Cornell University Press, Ithaca, pp 77-92

Caro T, Hunter J (2008) Interspecific competition and predation in American carnivore families. Ethol Ecol Evol 20:295-324

Carroll C, Zielinski WJ, Noss RF (1999) Using presence-absence data to build and test spatial habitat models for the Fisher in the Klamath Region, USA. Conserv Biol 13:1344-1359

Coonan TJ, Schwemm CA, Roemer GW, Garcelon DK, Munson L (2005) Decline of an island fox subspecies to near extinction. Southwestern Nat 50:32-41

Creel S, Creel NM (1996) Limitation of African wild dogs by competition with larger carnivores. Conserv Biol 10:526-538 
Davis FW, Seo C, Zielinski WJ (2007) Regional variation in home-range-scale habitat models for fisher (Martes pennanti) in California. Ecol Appl 17:2195-2213

De'ath G, Fabricius KE (2000) Classification and regression trees: a powerful yet simple technique for ecological data analysis. Ecology 81:3178-3192

Ewen JG, Armstrong DP, Parker KA, Seddon PJ (eds) (2012) Reintroduction biology, 1st edn. Wiley-Blackwell, Oxford

Gilbert JH (2000) Impacts of reestablished fishers on bobcat populations in Wisconsin. Dissertation, University of Wisconsin-Madison, Madison

Gorini L, Linnell JD, May R, Panzacchi M, Boitani L, Odden M, Nilsen EB (2012) Habitat heterogeneity and mammalian predator-prey interactions. Mamm Rev 42:55-77

Hansen K (2007) Bobcat: master of survival, 1st edn. Oxford University Press, New York

Heezik YV, Seddon PJ, Maloney RF (1999) Helping reintroduced houbara bustards avoid predation: effective antipredator training and the predictive value of pre-release behavior. Anim Conserv 2:155-163

Ingram R (1973) Wolverine, fisher, and marten in Central Oregon. Central Region Administrative Report. Oregon State Game Commission, Salem

Jacobson JE, Lewis JC, Snyder MC (2003) Assessment of fisher habitat in Washington State. Tier 1 Refinement and Tier 2 Final Report. Washington Department of Fish and Wildlife, Olympia

Knick ST, Brittell JD, Sweeney SJ (1985) Population characteristics of bobcats in Washington state. J Wildl Manag 49:721-728

Koehler GM, Hornocker MG (1989) Influences of seasons on bobcats in Idaho. J Wildl Manag 53:197-202

Koehler GM, Hornocker MG (1991) Seasonal resource use among mountain lions, bobcats, and coyotes. J Mammal 72:391-396

Krohn WB, Elowe KD, Boone RB (1995) Relations among fishers, snow, and martens: development and evaluation of two hypotheses. For Chron 71:97-105

Lewis JC (2013) Implementation plan for reintroducing fishers to the Cascade Mountain Range in Washington. Washington Department of Fish and Wildlife, Olympia

Lewis JC (2014) Post-release movements, survival, and resource selection of fishers (Pekania pennanti) translocated to the Olympic Peninsula of Washington. Dissertation, University of Washington

Lewis JC, Hayes GE (2004) Feasibility assessment for reintroducing fishers to Washington. Final Report. Washington Department of Fish and Wildlife, Olympia

Lewis JC, Happe PJ, Jenkins KJ, Manson DJ (2011) Olympic fisher reintroduction project: progress report 2008-2011. Washington Department of Fish and Wildlife, Olympia

Lewis JC, Powell RA, Zielinski WJ (2012) Carnivore translocations and conservation: insights from population models and field data for fishers (Martes pennanti). PLoS One 7:e32726

Litvaitis JA, Tash JP, Stevens CL (2006) The rise and fall of bobcat populations in New Hampshire: relevance of historical harvests to understanding current patterns of abundance and distribution. Biol Conserv 128:517-528

Lofroth EC, Raley CM, Finley LL, Naney RH (2010) Conservation of fishers (Martes pennanti) in south-central British
Columbia, western Washington, western Oregon, and California. USDI Bureau of Land Management, Denver

Long RA, Donovan TM, MacKay P, Zielinski WJ, Buzas JS (2010) Predicting carnivore occurrence with noninvasive surveys and occupancy modeling. Landscape Ecol 26:327-340

Mao JS, Boyce MS, Smith DW, Singer FJ, Vales DJ, Vore JM, Merrill EH (2005) Habitat selection by elk before and after wolf reintroduction in Yellowstone National Park. J Wildl Manag 69:1691-1707

McCleery R, Oli MK, Hostetler JA, Karmacharya B, Greene D, Winchester C, Gore J, Sneckenberger S, Castleberry SB, Mengak MT (2013) Are declines of an endangered mammal predation-driven and can a captive breeding and release program aid their recovery? J Zool 291:59-68

Moehrenschlager A, List R, Macdonald DW (2007) Escaping intraguild predation: Mexican kit foxes survive while coyotes and golden eagles kill Canadian swift foxes. J Mammal 88:1029-1039

Moseby KE, Read JL, Paton DC, Copley P, Hill BM, Crisp HA (2011) Predation determines the outcome of 10 reintroduction attempts in arid South Australia. Biol Conserv 144:2863-2872

Muñoz J, Felicísimo ÁM (2004) Comparison of statistical methods commonly used in predictive modelling. J Veg Sci 15:285-292

Neale JCC, Sacks BN (2001) Resource utilization and interspecific relations of sympatric bobcats and coyotes. Oikos 94:236-249

Ormerod SJ (2002) Applied issues with predators and predation: editor's introduction. J Appl Ecol 39:181-188

Poessel SA, Breck SW, Biggins DE, Livieri TM, Crooks KR, Angeloni L (2011) Landscape features influence postrelease predation on endangered black-footed ferrets. J Mammal 92:732-741

Powell R (1993) The fisher: life history, ecology, and behavior, 2nd edn. University of Minnesota Press, Minneapolis

Purcell KL, Mazzoni AK, Mori SR, Boroski BB (2009) Resting structures and resting habitat of fishers in the southern Sierra Nevada, CA. For Ecol Manag 258:2696-2706

Roy KD (1991) Ecology of reintroduced fishers in the Cabinet Mountains of northwestern Montana. Thesis, University of Montana, Missoula

Schwartz MK (2007) Ancient DNA confirms native Rocky Mountain fisher (Martes pennanti) avoided early 20th century extinction. J Mammal 88:921-925

Scheller RM, Spencer WD, Rustigian-Romsos H, Syphard AD, Ward BC, Strittholt JR (2011) Using stochastic simulation to evaluate competing risks of wildfires and fuels management on an isolated forest carnivore. Landscape Ecol 26:1491-1504

Schwartz MK, DeCesare NJ, Jimenez BS, Copeland JP, Melquist WE (2013) Stand- and landscape-scale selection of large trees by fishers in the Rocky Mountains of Montana and Idaho. For Ecol Manage 305:103-111

Seddon PJ, Armstrong DP, Maloney RF (2007) Developing the science of reintroduction biology. Conserv Biol 21:303-312

Slauson KM, Baldwin JA, Zielinski WJ (2012) Occupancy estimation and modeling in martes research and monitoring. In: Aubry KB, Zielinski WJ, Raphael MG, Proulx G, Buskirk SW (eds) Biology and conservation of martens, 
sables, and fishers: a new synthesis. Cornell University Press, Ithaca, pp 343-368

Spencer WD, Rustigian-Romsos H, Strittholt J, Scheller R, Zielinski WJ, Truex R (2011) Using occupancy and population models to assess habitat conservation opportunities for an isolated carnivore population. Biol Conserv 144:788-803

Tucker SA, Clark WR, Gosselink TE (2008) Space use and habitat selection by bobcats in the fragmented landscape of South-Central Iowa. J Wildl Manag 72:1114-1124

Vinkey RS, Schwartz MK, McKelvey KS, Foresman KR, Pilgrim KL, Giddings BJ, Lofroth EC (2006) When reintroductions are augmentations: the genetic legacy of fisher (Martes pennanti) in Montana. J Mammal 87:265-271

Wengert G (2013) Ecology of intraguild predation on fishers (Martes pennanti) in California. Dissertation, University of California, Davis

Wengert GM, Gabriel MW, Matthews SM, Higley JM, Sweitzer RA, Thompson CM, Purcell KL, Barrett RH, Woods LW, Green RE, Keller SM, Gaffney PM, Jones M, Sacks BN (2014) Using DNA to describe and quantify interspecific killing of fishers in California. J Wildl Manag 78:603-611
Yackulic CB, Reid J, Nichols JD, Hines JE, Davis R, Forsman E (2014) The roles of competition and habitat in the dynamics of populations and species distributions. Ecology 95:265-279

Zielinski WJ, Kucera TE (1995) American marten, fisher, lynx, and wolverine: survey methods for their detection. General Technical Report PSW-GTR-157. USDA Forest ServicePacific Southwest Research Station, Albany

Zielinski WJ, Truex RL, Ogan C, Busse K (1997) Detection surveys for fishers and American martens in California, 1989-1994: summary and interpretations. In: Proulx G, Bryant HN, Woodard PM (eds) Martes: taxonomy, ecology, techniques, and management. The Provincial Museum of Alberta, Edmonton, pp 372-392

Zielinski WJ, Truex RL, Schmidt GA, Schelexer FV, Schmidt $\mathrm{KN}$, Barrett RH (2004) Home range characteristics of fishers in California. J Mammal 85:649-657

Zielinski WJ, Dunk JR, Yaeger JS, LaPlante DW (2010) Developing and testing a landscape-scale habitat suitability model for fisher (Martes pennanti) in forests of interior northern California. For Ecol Manag 260:1579-1591 